\title{
Antimicrobial Properties and Chemical Composition of the Essential Oil of Leucobryum glaucum (Leucobryaceae)
}

\author{
Gonca ÇELIK' ${ }^{*}$ iD
}

${ }^{1}$ Karadeniz Technical University, Faculty of Science, Department of Chemistry, Trabzon, TURKEY

\begin{tabular}{lll}
\hline Received: 01 May 2020 & Revised: 17 May 2020 & Accepted: 09 June 2020
\end{tabular}

\begin{abstract}
In this study, a detailed study of the essential oil from Leucobryum glaucum (Hedw.) Angstr. was evaluated by gas chromatography/flame ionization detector (GC/FID) and gas chromatography/mass spectrometry (GC/MS) methods as well as screened for antibacterial activities of the essential oil and solvent extracts ( $n$-hexane and methanol). According to the results, a total of 47 compounds were detected, among which thujopsadiene $(35.5 \%)$ and $\beta$-curcumene $(25.4 \%)$ were the main components. In the second part of this study, the essential oil and solvent extracts were tested for its antimicrobial activity against 9 microorganisms with minimal-inhibitory-concentration (MIC) values in the range 61-4235 $\mu \mathrm{g} /$ $\mathrm{mL}$.
\end{abstract}

Keywords: Leucobryum glaucum, Essential oil, Solvent extract, GC-FID/MS, Antimicrobial activity

\section{Leucobryum glaucum (Leucobryaceae)'un Uçucu Yağının Kimyasal Bileşimi ve Antimikrobiyal Özellikleri}

$\ddot{O} z$

Bu çalışmada, Leucobryum glaucum (Hedw.) Angstr.'nin uçucu yağının detaylı çalışması gaz kromatografisi/ alev iyonlaştırma dedektörü (GC/FID) ve gaz kromatografisi/ kütle spektrometresi ile değerlendirildi hem de uçucu yağ ve çözücü ekstraktlarının ( $n$-hekzan ve metanol) antimikrobiyal aktivitesi incelendi. Sonuçlara göre, thujopsadien $(\% 35,5)$ ve $\beta$-curcumen $(\% 25,4)$ başlica bileşenler olmak üzere toplamda 47 bileşik belirlendi. Çalışmanın ikinci kısmında ise uçucu yağ ve çözücü ekstraktlarının antimiktobiyal aktivitesi 9 mikroorganizmaya karşı minimum-inhibisyon-konsantrasyonu (MİK) değerleri 61-4235 $\mu \mathrm{g} / \mathrm{mL}$ aralığında test edildi.

Anahtar kelimeler: Leucobryum glaucum, Uçucu yăg, Çözücü ekstraktı, GC-FID/MS, Antimikrobiyal aktivite

\footnotetext{
* Corresponding author: mavi_gnc@hotmail.com

(C) 2020 All rights reserved / Tüm haklarl saklıdır.

To cite this article: Çelik G. 2020. Antimicrobial Properties and Chemical Composition of the Essential Oil of Leucobryum glaucum (Leucobryaceae). Anatolian Bryology. 6:2, 112-118.

(c) (1) ()
} 


\section{Introduction}

Bryophytes, which are separated into three classes: Bryophyta (mosses), Marchantiophyta or Hepaticae (liverworts), and Anthocerotophyta (hornworts), consist of 25,000 species of mosses (Bryophyta) in the wide-spread in almost every part of our world (Saritas et al., 2001; Pannequin et al., 2017).

The species of Leucobryum glaucum (Hedw.) Angstr. related to the Leucobryaceae family (Bryophytes). The mosses of the genus Leucobryum is represented by 2 taxa, in Turkey. Many species from Bryophytes were used in folk medicine for various purposes in the world. In fact, besides its use as pharmacological activities, and for its antibacterial, antitumor, antiseptic, anticoagulant, insect antifeedant, nerve protecting, and cytotoxic qualities, providing at the same time (Boyom et al., 2003; Li and Zhao, 2009; Tosun et al., 2015). Additionally, previous studies have reported that the members of mosses have rich content including terpenoids, phenolics, glycosides, fatty acids, and the same rare aromatic compounds (Zeinsmeister and Mues, 1987; Zeinsmeister, et al., 1991; Jockovic et al., 2008; Sabovljević et al., 2009; Sabovljević et al., 2010). Recent phytochemical researches revealed that the dominant chemical essential oil components of mosses were aldehydes, terpenes, and aliphatic and aromatic compounds (Üçüncü et al., 2010; Cansu et al., 2013; Tosun et al., 2014). In contrast studies on the volatile composition and essential oil of mosses are still incompletely known (Tosun et al., 2015; Valarezo et al., 2018).

Our study represents the first and significant addition to solve the importance of the chemical composition of essential oil and antimicrobial activities of essential oil and solvent extracts in mosses in Turkey. Due to this, this paper aimed to identify the essential oil composition of $L$. glaucum and essential oil and solvent extracts ( $n$ hexane and methanol) antimicrobial activities were investigated.

\section{Material and Method}

\subsection{Sample collection}

L. glaucum was collected from Ordu-Turkey (altitude: 1560-1700 m) in September 2013. The mosses were identifications immediately after collection. Voucher specimen diagnosed (Uyar and Çetin, 2004; Fedosov and Ignatova, 2009;) by Assoc. Prof. Dr. Nevzat BATAN and deposited in the Herbarium of the Department of Biology (KTUB: 1609), Faculty of Science, Karadeniz Technical University, Turkey. Plant material cleaned to remove any residual compost, dried under the shadow, and stored in an air-tight container until use and grounded before use.

\subsection{Isolation of essential oil}

The essential oil of L. glaucum was obtained from the air-dried above the ground part of the moss ( 85 g) by hydrodistillation in a Clevenger-type apparatus with a cooling bath $\left(-15{ }^{\circ} \mathrm{C}\right)$ system $(3$ h) [yields: $0.05 \%(\mathrm{w} / \mathrm{w})$ ]. The obtained oils were dissolved in HPLC grade $n$-hexane $(0.5 \mathrm{~mL})$, dried over anhydrous sodium sulfate and stored at $4{ }^{\circ} \mathrm{C}$ in a sealed brown vial. Two $\mu \mathrm{L}$ of the essential oil was directly injected into the GC-FID/MS instrument.

\subsection{Solvent (hexane and methanol) extracts}

Air-dried grounded whole part of L. glaucum (10 $\mathrm{g}$, each) extracted with $n$-hexane and methanol to give $0.035 \mathrm{~g}$ and $0.675 \mathrm{~g}$ extracts, respectively.

\subsection{Gas Chromatography-Mass Spectrometry (GC-FID/MS)}

GC analysis performed using a gas chromatography device (Shimadzu GC 2010 Plus, Kyoto, Japan) attached to a mass selective detector (Shimadzu QP2010 Ultra, Kyoto, Japan) according to the previously described method (Renda et al., 2016). The separation was carried out using a Restek Rxi-5MS capillary column (Bellefonte, PA, USA) $60 \mathrm{~m}$ length, $0.25 \mathrm{~mm}$ i.d. and a $0.25 \mu \mathrm{m}$ phase thickness in split mode. The carrier gas was helium $(99.99 \%)$ at a constant flow rate of $1 \mathrm{~mL} / \mathrm{min}$. Detection was implemented in electronic impact mode (EI); ionization voltage was fixed at $70 \mathrm{eV}$, scan mode $(40-450 \mathrm{~m} / \mathrm{z})$ was used for mass acquisition.

Volatile compounds were compared to their retention index (RIs) (relative to $\mathrm{C}_{6}-\mathrm{C}_{30} n$-alkane standards) for identification (Adams, 2004). Mass spectral data were compared to those held in the FFNSC1.2 and W9N11 library of mass spectra (Bicchi et al., 2008; Kahriman et al., 2011; Özgenç et al., 2017). The sample was analyzed and the mean reported.

\subsection{Antimicrobial activity}

All tested microorganisms were obtained from the Refik Saydam Hifzissihha Institute (Ankara, Turkey). These were Escherichia coli (ATCC 25922), Yersinia pseudotuberculosis (ATCC 911), Pseudomonas aeruginosa (ATCC 43288), Staphylococcus aureus (ATCC 25923), Enterococcus faecalis (ATCC 29212), Bacillus cereus (709 Roma), Mycobacterium smegmatis (ATCC 607), Candida albicans (ATCC 60193), Candida tropicalis (ATCC 13803) and 
Saccharomyces cerevisiae (RSKK 251). The essential oil was dissolved in $n$-hexane $(84.700$ $\mu \mathrm{g} / \mathrm{mL}$ ) and solvent extracts were dissolved in dimethyl-sulphoxide (99.0\%) (DMSO) to prepare extract solution within the range of $19.700-150.200 \mu \mathrm{g} / \mathrm{mL}$. The screening results are shown in Table 2.

\subsection{Agar dilution MIC assay}

The antimicrobial effects of the essential oil, $n$ hexane, and methanol extracts were tested quantitatively in respective broth media by using the agar well diffusion method, and the minimal inhibition concentration (MIC) values $(\mu \mathrm{g} / \mathrm{mL}$ ) were examined and used in our previous work (Ahmad et al., 1998; Villanova, 1999; Tosun et al., 2014). The antibacterial and antifungal assays were performed in Mueller-Hinton broth (MH) (Difco, Detroit, MI) at pH 7.3 and buffered Yeast Nitrogen Base (Difco, Detroit, MI) at $\mathrm{pH}$ 7.0 , respectively. The microdilution test plates were incubated for $18-24 \mathrm{~h}$ at $35^{\circ} \mathrm{C}$. Brain Heart Infusion broth (BHI) (Difco, Detriot, MI) was used for M. smegmatis, and incubated for 48-72 $\mathrm{h}$ at $35{ }^{\circ} \mathrm{C}$ (Wood et al., 2003). The MIC was defined as the lowest concentration that showed no growth. Ampicillin $(10,000 \mu \mathrm{g} / \mathrm{mL})$, streptomycin $(10.000 \mu \mathrm{g} / \mathrm{mL})$, and fluconazole $(2.000 \mu \mathrm{g} / \mathrm{mL})$ were used as a standard antibacterial and antifungal drug, respectively. Dimethyl-sulfoxide (DMSO) with a dilution of 1:10 was used as solvent control.

\section{Results and Discussion}

\subsection{Chemical composition}

The essential oil L. glaucum (aerial parts) was obtained by hydrodistillation producing a yellow colored essential oil in the range of $0.05 \%(w / w)$. The combination of the essential oil of $L$. glaucum was identified by GC-FID and GC-MS and the components were determined by the association of their linear retention indices rates (against $\mathrm{C}_{6}-\mathrm{C}_{30} n$-alkanes on Restek Rxi-5MS capillary column) and mass spectra under identical experimental conditions (Table 1) (Üçüncü et al., 2010; Kahriman et al., 2011; Cansu et al., 2013; Tosun et al., 2015; Renda et al., 2016; Özgenç et al., 2017). The chemical components of the essential oil were grouped into nine classes, which were terpene/terpenoids (monoterpene hydrocarbon, oxygenated monoterpene, sesquiterpene hydrocarbons, oxygenated sesquiterpenes), aliphatic hydrocarbons, aldehydes, ketones, alcohols, and other in Table 1. The chemical profile explained that essential oil contained 47 specific constituents, which accounted for $98.6 \%$ of the total amount. L. glaucum essential oil was included 1 monoterpene hydrocarbon $(0.1 \%), 1$ oxygenated monoterpene $(0.1 \%), \quad 15$ sesquiterpene hydrocarbons $(73.6 \%)$, and 9 oxygenated sesquiterpenes $(19.5 \%)$. These chemical class variations of the mosses could be connected to the climatic conditions and environmental agents for example, ecospecies, location, season, soil properties, age of the plant, and extraction techniques (Tosun et al., 2015).

Looking at the consequences of the essential oil of L. glaucum, four of the most abundant components of this moss were thujopsadiene (31; $35.5 \%), \beta$-curcumene $(36 ; 25.4 \%)$, cedrol (43; $7.6 \%)$ and cis-isolongifolene $(44 ; 5.0 \%)$. The chemical components of the essential oil of $L$. glaucum presented in this study were parallel and different following previous reports (Cansu et al., 2013; Sim-Sim et al., 2017; Valarezo, et al., 2018). For example, it was reported that essential oils of the mosses, was rich in monoterpene hydrocarbons ( $\alpha$ - and $\beta$-pinene, camphene, $p$ cymene, myrecene, limonene, $\alpha$-terpinene, and camphor) and aldehydes (n-heptanal, n-octanal, n-nonanal, 2(E),4(E)-decadienal, $2(E), 4(Z)$ decadienal, n-tetradecanal, benzaldehyde, and benzene acetaldehyde) with high percentages (Shaw and Goffinet, 2000; Adams, 2004; Özdemir et al., 2009; Tosun et al., 2014). Similarly, Üçüncü et al. presented of the essential oils of mosses Tortula muralis Hedw., Homalothecium lutescens (Hedw.) H. Rob., Hypnum cupressiforme Hedw. and Pohlia nutans (Hedw.) Lindb. from Turkey were rich in aliphatic and aromatic aldehydes: n-heptanal, nnonanal, 2(E),4(E)-decadienal, benzaldehyde, phenylacetaldehyde, aliphatic alcohols: noctanol, 1-octen-3-ol, and hydrocarbons: C12C18, saturated, mono- and di- unsaturated (Üçüncü et al., 2010). In the essential oil of mosses species from Ecuador, ninety-four constituents were identified, the major components were epizonarene $(8.7 \%)$ and $\alpha$ selinene $(6.7 \%)$ in the oil of Breutelia tomentosa, $\beta$-selinene $(13.5 \%)$ and $\alpha$-selinene $(10.5 \%)$ in the oil of Leptodontium viticulosoides, selina-3,11dien-6- $\alpha$-ol $(19.7 \%)$ and curcuphenol (10.6\%) in the oil of Macromitrium perreflexum, epi- $\alpha$ muurulol $(15.1 \%)$ and $\alpha$-cadinol $(12.5 \%)$ in the oil of Campylopus richardii, $\alpha$-cadinol (36.8\%) and $\alpha$-santalene $(8.4 \%)$ in the oil of Rhacocarpus purpurascens, and phytol $(21.7 \%)$ and valerenol $(10.1 \%)$ in the oil of Thuidium peruvianum (Valarezo et al., 2018). Our results are in agreement which reported that aldehydes $(3.8 \%)$, among which hexanal $(1 ; 1.2 \%)$ were the important constituent in the essential oils of $L$. glaucum. In contrast to the previously reported, 
our analysis of the essential oil of L. glaucum in Turkey found that sesquiterpene hydrocarbons and oxygenated sesquiterpenes were the dominant class (Özdemir et al., 2009; Üçüncü et al., 2010; Cansu et al., 2013; Tosun et al., 2014; Tosun et al., 2015).

Table 1. Essential oil compounds identified from L. glaucum.

\begin{tabular}{|c|c|c|c|c|}
\hline & & $\mathbf{A}$ & & \\
\hline No & Compounds & $\operatorname{Area}^{b}(\%)$ & Exp.RI $^{\mathrm{a}}$ & Ident.LRI \\
\hline 1 & Hexanal & 1.2 & 817 & 802 \\
\hline 2 & Heptan-2-one & 0.1 & 900 & 892 \\
\hline 4 & Heptanal & 0.2 & 909 & 902 \\
\hline 5 & 2(E)-Heptenal & 0.1 & 962 & 959 \\
\hline 6 & 1-Octene-3-ol & 0.2 & 982 & 979 \\
\hline 7 & 3-Octanone & 0.1 & 990 & 984 \\
\hline 8 & 2-Amylfuran & 0.3 & 996 & 991 \\
\hline 9 & Octanal & 0.2 & 1006 & 999 \\
\hline 10 & $\alpha$-Terpinene & 0.1 & 1010 & 1017 \\
\hline 11 & Benzene acetaldehyde & 0.1 & 1050 & 1042 \\
\hline 12 & 2(E)-Octenal & 0.1 & 1062 & 1055 \\
\hline 13 & Octanol & 0.2 & 1071 & 1068 \\
\hline 14 & Nonanal & 1.2 & 1106 & 1101 \\
\hline 15 & 2(E)-Nonenal & 0.1 & 1163 & 1162 \\
\hline 16 & Decanal & 0.1 & 1208 & 1202 \\
\hline 17 & 2(E)-Decenal & 0.1 & 1265 & 1264 \\
\hline 18 & $2(E), 4(Z)$-Decadienal & 0.1 & 1298 & 1293 \\
\hline 19 & Tridecane $^{c}$ & 0.1 & 1300 & 1300 \\
\hline 20 & Undecanal & 0.1 & 1310 & 1307 \\
\hline 21 & $2(E), 4(E)$-Decadienal & 0.2 & 1321 & 1317 \\
\hline 22 & Bicycloelemene & 1.6 & 1348 & 1333 \\
\hline 23 & Eugenol & 0.1 & 1361 & 1359 \\
\hline 24 & $\beta$-Bourbonene & 0.2 & 1390 & 1388 \\
\hline 25 & Tetradecane $^{\mathrm{c}}$ & 0.5 & 1403 & 1400 \\
\hline 26 & Longifolene & 0.2 & 1411 & 1408 \\
\hline 27 & (E)-Caryophyllene & 0.4 & 1422 & 1419 \\
\hline 28 & $\beta$-Ylangene & 3.7 & 1429 & 1421 \\
\hline 29 & $\beta$-Copaene & 0.1 & 1436 & 1432 \\
\hline 30 & $\gamma$-Elemene & 1.4 & 1440 & 1437 \\
\hline 31 & Thujopsadiene & 35.5 & 1472 & 1468 \\
\hline 32 & $\gamma$-Gurjunene & 1.0 & 1481 & 1477 \\
\hline 33 & $\beta$-Selinene & 0.6 & 1493 & 1490 \\
\hline 34 & Valencene & 1.6 & 1499 & 1496 \\
\hline 35 & $(E)$ - $\beta$-Guaiene & 1.6 & 1508 & 1503 \\
\hline 36 & $\beta$-Curcumene & 25.4 & 1522 & 1516 \\
\hline 37 & Selina-3,7(11)-diene & 0.1 & 1550 & 1547 \\
\hline 38 & Germacrene B & 0.2 & 1563 & 1561 \\
\hline 39 & Ledol & 0.3 & 1573 & 1569 \\
\hline 40 & Spathulenol & 0.5 & 1579 & 1578 \\
\hline 41 & Caryophyllene oxide & 3.8 & 1589 & 1583 \\
\hline 42 & Viridiflorol & 0.5 & 1602 & 1593 \\
\hline 43 & Cedrol & 7.6 & 1609 & 1601 \\
\hline 44 & cis-Isolongifolene & 5.0 & 1617 & 1613 \\
\hline 45 & $\beta$-Eudesmol & 1.4 & 1643 & 1651 \\
\hline 46 & Valerianol & 0.1 & 1666 & 1658 \\
\hline 47 & Longifolol & 0.3 & 1718 & 1715 \\
\hline
\end{tabular}

Constituents

Monoterpene hydrocarbon

Oxygenated monoterpene

Sesquiterpene hydrocarbons

0.1

0.1




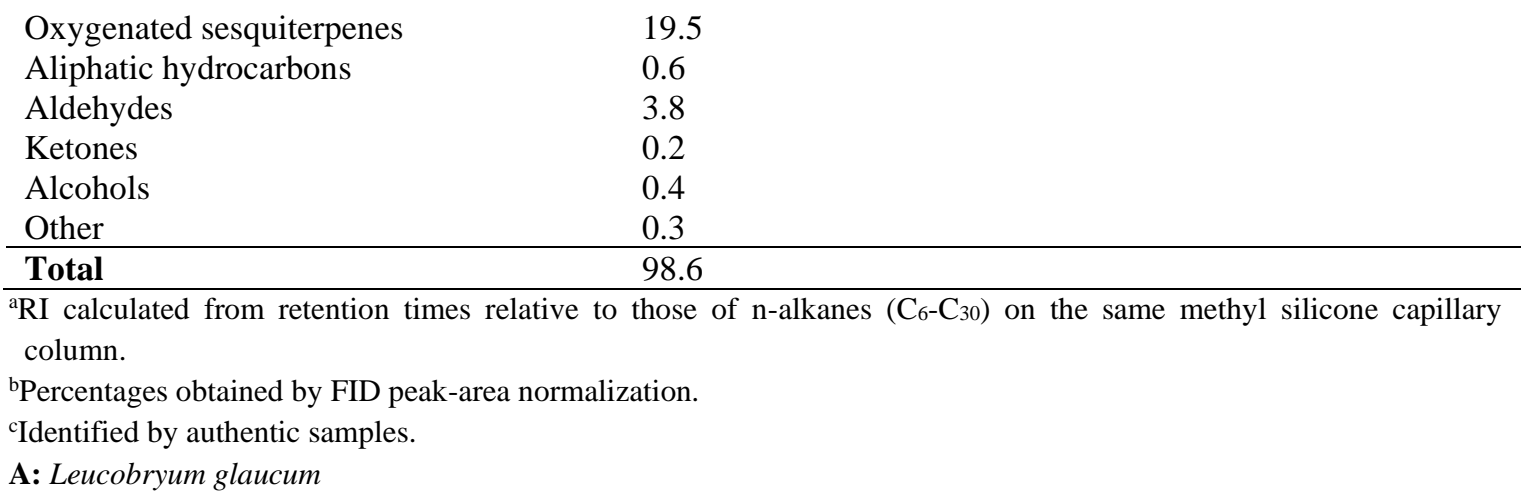

\subsection{Antimicrobial activity}

The antimicrobial activities of the essential oil and solvent extracts ( $n$-hexane and methanol) of L. glaucum were examined using minimalinhibitory-concentration (MIC) values with different microorganisms (strains of bacteria, yeast, and fungi), which are listed in Table 2 (Barry et al., 1999; Woods et al., 2003; Tosun et al., 2015). All analyzed examples moderate to low antibacterial activity against all ten microorganisms with the MIC values varied from $61 \mu \mathrm{g} / \mathrm{mL}$ to $4235 \mu \mathrm{g} / \mathrm{mL}$. Table 2 shows that, essential oil and solvent extracts ( $n$-hexane and methanol) from L. glaucum no antimicrobial activities against Gram-negative bacteria (Escherichia coli, Yersinia pseudotuberculosis, and Pseudomonas aeruginosa). In general, Staphylococcus aureus, Enterococcus faecalis, Bacillus cereus, Mycobacterium smegmatis, Candida albicans, and Saccharomyces cerevisiae (Gram-positive bacteria, acido-resistant mycobacterium, and yeast-like fungi) were selective microorganisms to the essential oil and solvent extracts ( $n$-hexane and methanol) of L. glaucum. In addition, if compared to that of all studied samples, the hexane extract of L. glaucum exhibited good antibacterial activity $(61-985 \mu \mathrm{g} / \mathrm{mL})$. The highest bioactivity was detected against Mycobacterium smegmatis with MIC values (61$405 \mu \mathrm{g} / \mathrm{mL})$.

Table 2. Screening for the antimicrobial activity of the essential oil and solvent extracts of L. glaucum.

\begin{tabular}{ll|cccccccccc}
\hline & Stock Sol. & \multicolumn{8}{c}{ Microorganisms and minimal inhibition concentration $(\mathbf{M I C}, \boldsymbol{\mu g} / \mathbf{m L})$} \\
\cline { 3 - 12 } Samples & $\boldsymbol{\mu g} / \mathbf{m L}$ & Ec & Yp & Pa & Ef & $\mathbf{L i}$ & Sa & Bc & Ms & Ca & Sc \\
\hline Essential oil & 84.700 & - & - & - & - & - & 4235 & 2117 & 405 & 4235 & 4235 \\
Methanol ext. & 150.200 & - & - & - & - & - & 938 & 469 & 117 & 469 & 234 \\
Hexane ext. & 19.700 & - & - & - & - & - & 123 & 61 & 61 & 985 & 985 \\
\hline Amp. & 10 & 10 & 18 & $>128$ & 10 & 10 & 35 & 15 & & & \\
Strep. & 10 & & & & & & & & 4 & & $<8$ \\
Flu & 5 & & & & & & & & & $<8$ & $<8$
\end{tabular}

Ec: Escherichia coli (ATCC 25922), Yp: Yersinia pseudotuberculosis (ATCC 911), Pa: Pseudomonas aeruginosa (ATCC 27853), Sa: Staphylococcus aureus (ATCC 25923), Ef: Enterococcus faecalis (ATCC 29212), Li: Listeria monocytogenes (ATCC 43251), Bc: Bacillus cereus (709 Roma), Ms: Mycobacterium smegmatis (ATCC607), Ca: Candida albicans (ATCC 60193), Sc: Saccharomyces cerevisiae (RSKK 251), Amp.: Ampicillin, Strep.: Streptomycin, Flu.: Fluconazole, —: no activity of test concentrations.

\section{Acknowledgments}

The author is grateful to Professor Şengül Alpay Karaoğlu (Recep Tayyip Erdoğan University, Faculty of Science, Department of Biology) for the help in the antimicrobial activity test. We also thank Associate Professor Nevzat Batan (Karadeniz Technical University, Maçka Vocational School) for the help in diagnose of the species. The author acknowledges the financial support from The Scientific and
Technological Research Council of Turkey (TUBITAK) with Project $113 Z 228$.

\section{References}

Adams R.P. 2004. Identification of essential oil components by gas chromatography/quadrupole mass spectroscopy. Carol Stream, IL: Allured Publication.

Ahmad I. Mehmood Z. Mohammad F. 1998. Screening of some Indian medicinal 
plants for their antimicrobial properties. Journal of Ethnopharmacology. $\quad 62$ : 183-193.

Barry A.L. Craig W.A. Nadler H. Reller L.B. Sander C.C. Swenson J.M. 1999. Methods for Determining Bactericidal Activity of antimicrobial Agents. Approved Guideline, NCCLS. 19: 1-29.

Bicchi C. Cordero C. Liberto E. Sgorbini B. Rubiolo P. 2008. Headspace sampling of the volatile fraction of vegetable matrices. Journal of Chromatography A. 1184: 220-233.

Boyom F.F. Ngouana V. Amvam Zollo P.H. Menut C. Bessiere J.M. Gut J. Rosenthal P.J. 2003. Composition and anti-plasmodial activities of essential oils from some Cameroonian medicinal plants. Phytochem. 64: 1269. 1275.

Cansu T.B. Yaylı B. Özdemir T. Batan N. Alpay Karaoğlu Ş. Yaylı N. 2013. Antimicrobial activity and chemical composition of mosses (Hylocomium splendens (Hedw.) Schimp. and Leucodon sciuroides (Hedw.) Schwägr) growing in Turkey. Turkish Journal of Chemistry. 37: 213-219.

Fedosov V.E. Ignatova E.A. 2009. Tortella Densa (Pottiaceae, Bryophyta) in Russia. Arctoa. 18: 189-194.

Jockovic N. Andrade P.B. Valentão P. Sabovljevic M. 2008. HPLC-DAD of phenolics in bryophytes Lunularia cruciata, Brachytheciastrum velutinum and Kindbergia praelonga. Journal of the Serbian Chamical Society. 73: 1161-1167.

Kahriman N. Tosun G. Terzioglu S. Alpay Karaoğlu Ş. Yayli N. 2011. Chemical Composition and Antimicrobial Activity of the Essential Oils from the Flower, Leaf, and Stem of Senecio pandurifolius. Record of Natural Products. 5: 82-91.

Li L. Zhao J. 2009. Determination of the Volatile Composition of Rhodobryum giganteum (Schwaegr.) Par. (Bryaceae) using Solid-Phase Microextraction and Gas Chromatography/ Mass Spectrometry (GC/ MS). Molecules. 14: 21952201.

Özdemir T. Yaylı N. Cansu T.B. Volga C. Yaylı N. 2009. Essential Oils in Mosses (Brachythecium Eurhynchium pulchellum, and Plagiomnium undulatum) Grown in
Turkey. Asian Journal of Chemistry. 21: 5505-5509.

Özgenç Ö. Durmaz S. Çelik G. Korkmaz B. Yaylı N. 2017. Comparative phytochemical analysis of volatile organic compounds by SPME-GCFID/MS from six coniferous and nine deciduous tree bark species grown in Turkey. South African Journal of Botany. 113: 23-28.

Pannequin A. Tintaru A. Desjobert J.M. Costa J. Muselli A. 2017. New advances in the volatile metabolites of Frullania tamarisci. Flavour and Fragnance Journal. 32: 409-418.

Renda G. Tosun G. Yaylı N. 2016. SPME GC/MS Analysis of Three Ornithogalum L. species from Turkey. Records of Natural Products. 10: 497-502.

Sabovljević A. Sabovljevic M. Jockovic N. 2009. In vitro culture and secondary metabolite 1solation in Bryophytes. In: Mohan Jain S and Saxena PK (eds) Methods in Molecular Biology: Protocols for in vitro cultures and secondary metabolite analysis of aromatic and medicinal plants. Humana Press. 547: 117-128.

Sabovljević A. Sokovic M. Glamočlija J. Ćirić A. Vujičić M. Pejin B. Sabovljević M. 2010. Comparison of extract bioactivities of in-situ and in-vitro grown selected bryophyte species. African Journal of Microbiology Research. 4: 808-812.

Shaw A.J. Goffinet B. 2000. Bryphyte Biology. Cambridge University Press, UK.

Saritas Y. Sonwa M.M. Iznaguen H. König W.A. Muhle H. Mues R. 2001. Volatile constituents in mosses (Musci). Phytochemistry. 57: 443-457.

Sim-Sim M. Abreu M. Garcia C. Sergio C. Figueiredo C. 2017. Essential Oil Composition of Two Sphagnum Species Grown in Portugal and their In-Vitro Culture Establishment. Natural Product Communications. 12: 1307-1310.

Tosun G. Yaylı B. Özdemir T. Batan N. Yaylı N. Alpay Karaoğlu Ş. 2014. Chemical Composition and Antimicrobial Activity of Essential Oils from Tortella inclinata var. Densa, T. tortusa and Pleurochaete squarrosa. Asian Journal of Chemistry. 26: 2001-2004.

Tosun G. Yaylı B. Özdemir T. Batan N. Bozdeveci A. Yayl1 N. 2015. Volatiles and Antimicrobial Activity of the Essential Oils of the Mosses 
Pseudoscleropodium purum,

Eurhynchium striatum, and Eurhynchium angustirete Grown in Turkey. Record of Natural Products. 9: 237-242.

Uyar G. Çetin B. 2004. A new check-list of the mosses of Turkey. Journal of Bryology. 26: 203-220.

Üçüncü O. Cansu T.B. Özdemir T. Alpay Karaoğlu Ş. Yaylı N. 2010. Chemical composition and antimicrobial activity of the essential oils of mosses (Tortula muralis Hedw., Homalothecium lutescens (Hedw.) H. Rob., Hypnum cupressiforme Hedw., and Pohlia nutans (Hedw.) Lindb.) from Turkey.

Turkish Journal of Chemistry. 34: 825834.

Valarezo E. Vidal V. Calva J. Jaramillo S.P. Febres J.D. Benitez A. 2018. Essential Oil Constituents of Mosses Species from Ecuador. Teop. 21: 189-197.
Villanova P.A. 1999. Methods for Determining Bactericidal Activity of Antimicrobial Agents; Approved Guideline. NCCLS, M26-A, Vol. 19.

Woods G.L. Brown-Elliott B.A. Desmond E.P. Hall G.S. Heifets L. Pfyffer G.E. Ridderhof J.C. Jr. Wallace R.J. Warren N.C. Witebsky F.G. 2003. Susceptibility testing of mycobacteria, nocardiae, and other aerobic actinomycetes; Approved Standard. NCCLS document, M24-A, Vol. 23.

Zinsmeister H.D. Becker H. Eicher T. 1991. Bryophytes, a source of biologically active, naturally occurring material. Angewandte Chemie International Edition in English. 30, 130-147.

Zinsmeister H.D. Mues R. 1987. Moose as reservoir remarkable sekundärer. Ingredients GIT Mag. Lab. 31: 499-512. 